\title{
ANALYSIS OF COMMUNITY PERCEPTION OF PUBLIC SERVICE QUALITY IN OFFICE SOCIAL INSURANCE ADMINISTRATION ORGANIZATION OF HEALTH (BPJS KESEHATAN) SURAKARTA CITY
}

\author{
Doni Mardiyanto \\ STIA-ASMI Solo, Indonesia \\ hlc.donsmart@gmail.com
}

\begin{abstract}
Public perceptions of the quality of government services in Indonesia generally assess service performance is not as expected, this can be seen, among others, from the many complaints or complaints from the community such as procedures and service mechanisms that are convoluted, not transparent, uninformed, less accommodative, less consistent, limited facilities, service facilities and infrastructure, so that it does not guarantee certainty (law, time, and costs) and there are still many practices of illegal levies and actions that indicate irregularities and service learning. The public perception of the implementation of public services at the Health Social Security Agency (BPJS) is still unknown, whether it resembles a public complaint, considering that government-owned enterprises are more oriented to public services rather than mere benefits. Therefore there is a need for a study to analyze how the public perception of service delivery. This research was conducted at the Office of the Surakarta City Social Security Agency (BPJS), with the aim of analyzing community perceptions of public service delivery and knowing the factors that influence the quality of public services. This study uses a quantitative approach with quantitative descriptive research methods, with survey techniques, namely the distribution of questionnaires to 48 respondents using the Surakarta City Health BPJS service. From the results of the analysis, it is known that the public perception of the users of public services at the Surakarta City Health Insurance Agency (BPJS) Office stated that the implementation of public services was satisfactory. The factors that influence the quality of public services at the Health Social Security Organizing Agency (BPJS) in Surakarta City are factors of education and income.
\end{abstract}

Keywords : Community Perception, Quality and Factors of Public Service. 


\section{INTRODUCTION}

The quality of health services is the degree to which the needs of the community or individuals meet health care in accordance with good professional standards by utilizing resources in a reasonable, efficient, effective manner within the limited capacity of the government and society, and safe and satisfying customers in accordance with the norms and ethics good (Azrul in Rinda Mustika, 2014). The burden of the State Budget (APBN) to provide funds for health services for the poor tends to increase until the future. To continue to guarantee health services for the poor, in its development since 1998 the government launched the Social Safety Net Program in the Field of Health (JPSBK). In 2001 the government also produced a program to combat the Impact of Health Energy Subsidy Reduction (PDPSE-BK) for health services in RS / BP4 / BKMM, provision of medicines for basic health services (PKD) and hepatitis B vaccines at Puskesmas and its networks. Then in 2003 a new mechanism was tested with the principle of health insurance, this mechanism is regulated in Law No. 40 of 2004 concerning the National Social Security System (SJSN). This mechanism is expected to be a controlled, effective, efficient and sustainable financing system, while increasing the quality and access of health services. Then as a continuation of the program, nationally with Decree No. 56 / Menkes / Kes / SK / I / 2005 since January 1, 2005, the Implementation of the Health Insurance Assurance Program for the Poor (PJKMM). Based on Decree No. 1241 /
Menkes / XI / I / 2004, the implementation of PJKMM is submitted to third parties PT. ASKES (Persero) works with related parties. Continued until 2011, based on Law No. 24 of 2011, there was a change in the implementation of health insurance from the previous PT. ASKES (Persero) becomes BPJS Kesehatan (Health Social Security Organizing Agency).

The Social Security Organizing Agency (BPJS) is an institution formed to organize social security programs in Indonesia according to Law Number 40 of 2004 and Law Number 24 of 2011 and based on Law Number 40 of 2004, BPJS is a nonprofit legal entity. The Social Security Organizing Agency (BPJS) is a public legal entity established to organize social security programs. BPJS consists of health BPJS and employment BPJS (Indonesian Ministry of Health, 2013: 2). In this case BPJS Kesehatan is a legal entity formed to organize health insurance programs (Ministry of Health, 2013: 3). All Indonesian residents must become health insurance participants managed by BPJS including foreigners who have worked for a minimum of six months in Indonesia and have paid contributions (Ministry of Health, 2013: 6). Through this program the government strives to always maintain access of the poor and even all residents of the country to health services that are still low and tend to decline so that in the future their health will continue to increase and be guaranteed. Based on the description above illustrated that the health insurance program has been carried out by the government to maintain and improve access to public health services. Of course to 
keep the program well implemented, it is necessary to evaluate it due to the frequent changes in policies and regulations in health service procedures.

The results of the Primary Data Processing previously showed that the public's interest in becoming a National Health Insurance (JKN) program managed by the Health BPJS was quite large. The latest data, BPJS Health participants reached 142 million people. Projections in 2015, the number of participants increased to 168 million people with 30 million people being wage-receiving workers (PPU). The composition of opinion of BPJS participants is also reflected in the Kompas poll. Of the 592 respondents from the Kompas R \& D poll in 12 cities, 53.5 percent had participated in the Health BPJS. Its composition, more than 60 percent of civil servants and retirees. However, of the 317 respondents who were participants in the JKN BPJS Health program, only 39.1 percent expressed satisfaction with BPJS services. As many as 42.9 percent of respondents using the BPJS Health service still expressed dissatisfaction. The dissatisfaction is based on their experience in various ways, ranging from the complexity of the procedure to obtaining services from membership registration to the time of examination.

For patients or the public, BPJS service users have an obligation to report changes in patient data, whether due to marriage, divorce, death, change of address or move to first-rate health facilities, and keep patient cards from being damaged, lost or utilized by unauthorized people, and obey all provisions and procedures for health services. In the BPJS, there is a service procedure where sick patients receive services where patients are registered with a BPJS Health card. As long as the Health BPJS card has not been received by the patient, a health card identity card or Membership Card and Family Card can be used. Public perceptions, especially of the people who use BPJS Health services, are one of the things that affect the level of utilization of health services. Positive public perceptions will influence the level of utilization of BPJS services. This shows that the quality or quality of service is valued by the community. Quality is a blend of the characteristics and characteristics of a product or service that can meet the needs of users or customers. The results of the Roekmito Primary Data Processing in Noviansyah Kristiani, 2006 stated that the health service quality factor perceived by the JPKM participants was a caring factor which was the willingness of the health service providers to respond or respond to the needs and desires of the participants immediately. With the existence of BPJS, the quality of services provided to patients has been determined. Most of these things affect the level of satisfaction of BPJS patients. BPJS patients should better understand the meaning of the enactment of BPJS to improve the health of Indonesian citizens from all groups. Where the application of the BPJS regulations is given equally to all BPJS participants with the same quality of service from each group. Services that are fast, friendly, uncomplicated and followed by clean, complete and comfortable service room facilities are certainly a top priority for BPJS Kesehatan as a public service institution. Therefore, the researcher is 
interested in conducting research with the title "Analysis of Community Perception of Service Quality at the Office of Health Social Security Organizing Agency (BPJS) of Surakarta City".

\section{LITERATURE REVIEW}

\subsection{Concept of Public Service}

The American Marketing Association, as quoted by Donald W, Cowell, 1984: 22 (in Riwan Novandy, 2009) states that; "Service is basically an activity or benefit offered by a party to another party and essentially intangible and does not produce ownership of something, the production process may and may not be associated with a physical product". The Ministry of Home Affairs (2004) states that; "Public Service is a Public Service", and defines "Public Service is a process of assistance to others in certain ways that require sensitivity and interpersonal relationships to create satisfaction and success. Every service produces a product, both in the form of goods and services.

The implementation of public services is carried out by public service providers, namely state / government organizers, providers of economy and development, independent institutions formed by the government, business entities / legal entities authorized to carry out some tasks and functions of public services, business entities /legal entities that cooperate and/or contracted to carry out part of the duties and functions of public services. And the general public or private sectors that carry out some tasks and functions of public services that are not able to be handled / managed by the government / regional government. There are 3 (three) important elements in public service, namely the first element, is the service provider (organizer) of service, namely the Regional Government. The second element is the recipient of the service (customer), namely the person or community or organization concerned, and the third element, is the satisfaction given and / or received by the recipient of the service (customer).

There are ten general service principles stipulated in the Decree of the State Minister for State Apparatus Empowerment Number 63 / KEP / M.PAN / 7/2003 concerning General Guidelines for the Implementation of Public Services, the ten principles are as follows; Simplicity; Clarity; Certainty of time; Accuracy; Security; Responsible; Completeness of work facilities and infrastructure, Ease of Access; Discipline, Courtesy and Hospitality; Convenience. To realize the ten principles of public service is not easy, because associated with the complex implementation of public services, many factors influence the achievement of optimal service performance. Factors that influence the performance of public services include; government apparatus as an organizer (HR quality); community or customers as users or recipients of public services; Legislation; mechanisms and procedures for implementing public services; supporting facilities for service delivery; institutions and sources of funding for public service operations, and the most decisive is the top leadership of the regional leadership to the central leadership. 


\subsection{Quality and Quality of Public Services}

In measuring the quality of a service, the model that is often used is the Servqual model of service quality, including: Reliability; dimensions of service quality in the form of the ability to provide optimal and accurate services and is a statement about the ability to fulfill promises. Tangibles; dimensions of service quality in the form of appearance of physical facilities, equipment, employee appearance and communication equipment. Empathy; dimensions of service quality about caring and genuine attention to consumers individually. Responsiveness; dimensions of service quality about the willingness to help consumers and provide services promptly and precisely. Assurance; dimensions of service quality in the form of guarantees that include politeness, knowledge and abilities of employees, security and can be trusted.

There are 5 (five) determinants of the quality of public services that can be detailed as follows (Parasuraman, Zeithami and Berry in Novandy, 2009): Reliability, namely the ability to carry out the promised service appropriately and reliably. Responsiveness, namely the ability to help customers and provide services quickly. Confidence, namely the knowledge and politeness of employees and their ability to generate trust and confidence or "assurance". Empathy, which is a condition for caring, gives personal attention to customers. Tangible, namely the appearance of physical facilities, equipment, personnel, and communication media.

\subsection{Community Perception}

Perception is a process by which an individual organizes an received stimulus and then interprets it, so that one can realize and understand what is received and this is also influenced by the experiences that are in themselves concerned. In general Indonesian dictionary perceptions are defined as a person's process of knowing things through their five senses or direct reception / response from an absorption. Whereas Robbins in the Organizational Behavior book defines perception as a process that individuals take to organize and interpret their sensory impressions to give meaning to their environment. However, what people perceive can be different from objective reality, because there are some that can affect one's perception.

The factors that influence perception are as follows: First, Perpetrators of Perception; If someone views an object and tries to interpret it, it is strongly influenced by the personal characteristics of the perception which includes attitudes, motives, interests, experiences and expectations. Second, Target / object; The characteristics of the target observed can affect what is perceived because the target is not seen as isolated, but adjacent objects will tend to be perceived together. The factors on the target include new things, movements, sounds, size, background, and closeness. Third, Situation; Besides these two things the situation also affects the individual's perception. This situation includes time, circumstances / place of work, and social conditions. 
In giving attention to consumers to be influenced must pay attention to several things (Sri Berdi Karyati, 2006), among others:

1) The consumer is king. Consumers have the full ability to adjust between those marketed with consumer motivation and behavior.

2) Consumer motivation and behavior can be understood through research.

3) Consumer behavior can be influenced through persuasive activities by realizing that consumers are the ruling party.

4) Influence on consumers has socially beneficial results provided legal, ethical, and moral safeguards are in place to curb manipulation efforts.

Everyone's perception of an object will be different, therefore perceptions have a subjective nature. Perception formed by someone is influenced by his memory. Solomon defines sensation as a rapid response from our receiving senses (eyes, ears, nose, mouth and fingers) to basic stimuli such as light, color and sound. While perception is the process of how the stimuli are selected, organized and interpreted.

\section{RESEARCH METHODS}

\subsection{Research Approach Perspective}

The perspective used in this study is quantitative data research with descriptive statistical methods, this describes or describes the characteristics of the variables studied or summarizes the results of observations that have been made. This method relates to the activities of recording, compiling, presenting, and summarizing by describing or describing the data which results from observations of events or phenomena quantitatively (Iskandar, 2008: 102). This study is intended to collect information about the status of a variable or theme, symptoms or conditions that exist, namely the state of symptoms (phenomena) according to what they were at the time of the study (Widodo \& Muchtar in Rimanawar in Rismannawar, 2005). Nasir (1988) defines a descriptive research method as a research method to draw a picture of a situation or event, so that this method intends to hold a mere accumulation of basic data. This research was conducted on the community of service users at the BPJS health office to assess how public services are in the Office of the Health Social Security Organizing Agency (BPJS) of Surakarta City. Service quality can be seen from the public perception of service users in the Surakarta City BPJS health office. From these perceptions, conclusions will be drawn regarding what factors influence the quality of public services.

\subsection{Population and Samples}

Population is a set of units that are usually in the form of people, objects, transactions or events where we are interested in learning (Kuncoro in Novandy Riwan 2009). In this study the intended population is people who use public services at the Office of the Health Social Security Organizing Agency (BPJS) of Surakarta City in the period of September 25-30 (5 days). Effective data collection is carried out for three days with a population of over 400 estimated times.

A sample is a subset (subset) of a population unit (Kuncoro, 2001). The sample from this study is part of the population taken 
as a source of data and can represent the entire population (community users of public services at the Office of Health Social Security Organizing Agency (BPJS) of Surakarta City. Sampling in this study must be a sample that represents the population. Therefore, sampling only for users of public services at the Surakarta Health Social Security Agency (BPJS) is one step to avoid biased and invalid results in research, if the sample does not represent the population, the results will be very dangerous ( Healey, 2002) The number of samples based on Roscoe's opinion as quoted by Sekaran (2006) that the sample size is greater than 30 and less than 500 is sufficient to be used in all studies.In this study the sample of respondents taken was 48 respondents. MPEL is determined by convinience sampling, which is a sample of respondents from the community / service users who are easily found at the research location. The basis of making this sampling technique is not a problem or a decrease in the quality of Primary Data Processing Results because however complicated the technique used will not guarantee representativeness, the most important is a sample that is representative or truly represents the population (Healey, 2002).

\subsection{Data Collection Technique}

The data collection technique is by collecting primary and secondary data. Secondary data sources are documents and archives of institutions at the Health Social Security Organizing Agency (BPJS Kesehatan). Primary data was collected from respondents using questionnaires or questionnaires. For primary data collection is done by distributing questionnaires to users of public services Office of the Social Security Organizing Agency (BPJS Kesehatan). The use of primary data is done to determine the public perception of the quality of public services and to know the factors that influence the quality of public services. The list of questions on the questionnaire was arranged based on variables that might affect the quality of public services, namely simplicity, clarity, certainty of time, accuracy, security, responsibility, completeness of work facilities and infrastructure (adequate work equipment and support including the provision of telecommunications and information technology facilities / teletematics), ease of access, discipline, courtesy, friendliness, and comfort.

\subsection{Analysis Method}

The main point of this research is to discuss the quality of public services carried out by the Office of the Health Social Security Organizing Agency (BPJS) of Surakarta City. Based on the subject of the research, the analysis approach of the research carried out is how the public perception of the quality of public services provided, and then understand the factors that influence the quality of public services.

The research approach can be carried out through several stages of research. The stages of this research approach include:

1) Conduct a literature review, which includes the collection of theories related to research topics such as public sector management theory, public service theory, and other influencing theories in research analysis. 
2) Collecting data and information, which includes primary data collection, namely by distributing questionnaires and secondary data as a support and basis for literature review, as well as compiling the questionnaire framework, determining the number of questionnaires, and distributing questionnaires in the research area.

3) Identify the characteristics of users of public services. Characteristics of users of public services can be assessed from gender, age, occupation, education, and monthly average income.

4) Determine the variables that are likely to influence the quality of public services. Determination of variables is done in a literature review and based on various specific considerations.

5) Knowing the perceptions of users of public services on the quality of public services of the Health Social Security Organizing Agency (BPJS) of Surakarta City.

6) Understand the factors that affect the quality of public services of the Office of the Health Social Security Organizing Agency (BPJS) of Surakarta City.

7) Based on the results of the analysis conducted the research conclusions can be drawn as a basis in determining the suggestions related to this study.

This descriptive research method is used to analyze the following things:

1) Public perception of the quality of public services Office of the Health Social Security Organizing Agency (BPJS) of Surakarta City.

2) Knowing the factors that influence the quality of public services at the Health
Social Security Organizing Agency (BPJS) of Surakarta City.

To find out the factors that affect the quality of public services at the Health Social Security Administering Agency (BPJS Kesehatan) of Surakarta City, crosstabulation (chi-square value) was conducted. Whether or not there is a relationship between the quality of public services at the Health Social Security Administering Agency (BPJS) of Surakarta City and the factors that might influence the quality of public services can be seen from the chisquare value. The output produced is the factors that influence the quality of public services at the Health Social Security Organizing Agency (BPJS) of Surakarta City.

So, the hypothesis proposed is:

Ho: There is no relationship between the quality of public services at the Health Social Security Administering Agency (BPJS) of Surakarta City and the factors that might affect the quality of public services.

H1: There is a relationship between the quality of public services at the Health Social Security Administering Agency (BPJS) of Surakarta City and the factors that might affect the quality of public services. Decision making that can be done is:

a. Based on the Chi-Square comparison $(\chi 2)$ Test and Table. (95\% confidence level; $\alpha$ $=5 \%$ )

If Chi-Square Count <Chi-Square Table, then Ho is accepted.

If Chi-Square Count> Chi-Square Table, then Ho is rejected.

b. Based on probability. 


\section{Vol-2, Issue-4, 2018 (IJEBAR)}

\section{ISSN: 2614-1280}

http://www.jurnal.stie-aas/ijebar

If the probability is $>0.05$, then $\mathrm{Ho}$ is accepted.

If the probability is $<0.05$, then $\mathrm{Ho}$ is rejected.

\section{RESULTS AND DISCUSSION}

The results of Primary Data Processing indicate that the majority of respondents are male. The most sexes are men, this is because many men come to the BPJS Health office to take care of their family's health insurance. According to Hungu (2007) gender (sex) is a difference between women and men biologically since a person is born. Biological differences and the biological functions of men and women cannot be exchanged between the two, and their functions remain with men and women in all races on the face of the earth.

The results of Primary Data Processing indicate that the majority of respondents were> 29 years old. Many of the respondents who visited the BPJS office with the age of $>29$ years were due to the fact that most of them were married and of course this kept the family from things that were unexpected. According to Hurlock (1998) the more the age, the level of maturity and strength of a person will be more mature in thinking and working. In terms of public trust, someone who is more mature is more trusted than someone who is not yet mature. This is seen from experience and maturity of his soul.

The results of Primary Data Processing indicate that the majority of respondents had high school education, this indicates that many respondents who had sufficient education. According to the
Dictionary of Education (2004) education is the process by which someone develops abilities, attitudes and other forms of behavior within the community. Based on these definitions, it can be interpreted that education is a tool used to change human behavior. Education can be interpreted as a process or activity to develop the personality and abilities of individuals or society. This means that education is a character formation that is an attitude accompanied by abilities in the form of intelligence, knowledge and skills. According to Daryanto (2007), education is an effort to increase humanity to the human level which is called educating. Education is any effort to foster a personality and develop human abilities physically and spiritually which lasts a lifetime, both inside and outside of school in the framework of building Indonesian unity and society (Hasibuan, 2005).

The results of Primary Data Processing indicate that the majority of respondents are having diverse jobs. Many respondents with various jobs, because they have free time during service hours, so they can take care of BPJS during formal working hours. Having a job someone will need a lot of time and need attention. Busy communities only have little time to be able to take care of social interests in working hours, so that in this study, formal workers were not found in the Surakarta City Health BPJS office.

The results of Primary Data Processing found good perceptions of the BPJS office services because the BPJS service procedures at the BPJS service office were quite easy and not complicated. The clerk was also friendly enough so that if there 
was a shortage of BPJS Health requirements the administration officer notified the shortcomings. Easily proven administrative services with administrative services at BPJS offices are also relatively fast, so many people are satisfied with the service. Facilities and infrastructure services are also quite good, as evidenced by the many respondents who agreed with the service facilities and infrastructure issues at the BPJS office.

With the existence of services both physically and non-physically as mentioned above, the community has a good perception of the BPJS office services. Perception is one of the important psychological aspects for humans in responding to the presence of various aspects and symptoms around it. Perception contains a very broad understanding, involving internal and external (Sugiharto, 2007). Community perceptions of Kanor BPJS Kesehatan services ranging from administrative services, BPJS Health patient services and good facilities and infrastructure services, it is proven that many respondents responded well to services at the BPJS Health Office. Large respondents have good perceptions of the services of the BPJS Health office which includes administration, BPJS patient services and facilities and infrastructure. In addition to good public perceptions of BPJS, there are several factors related to perception. The results of the analysis show that from the respondent characteristics, education and income factors are factors that are significantly related to the public perception of the quality of BPJS Health office services. The results of the analysis show the Pearson chi square value of 84.282 with a significance of 0.000 . Because the significance value is $<0.05$, then $\mathrm{Ho}$ is rejected and it is stated that there is a significant relationship between education and community perceptions of the quality of public health services in Surakarta City BPJS. While the income aspect obtained Pearson chi square results of 21.204 with a significance of 0.047 . Because the significance value is $<0.05$, then $\mathrm{Ho}$ is rejected and it is stated that there is a significant relationship between Income and community perceptions of the quality of public services in the Surakarta City BPJS Health Office.

It can be understood that with sufficient education, the public is aware of the importance of BPJS as a health insurance for themselves and their families. Likewise with income, the amount of income at the average income level in general, the community tends to guarantee more health towards health insurance institutions such as BPJS. Thus, with the existing education and income, the community has a good perception of the quality of service in the Office of BPJS Surakarta.

\section{CONCLUSION}

\subsection{Conclusion}

The public perception of the quality of public services at the Office of the Health Social Security Organizing Agency (BPJS) of Surakarta City is quite good. This is indicated by the average > 50\% of respondents answering or responding positively / good to the quality of public services.

Factors influencing the quality of public services at the Health Social Security 
Administering Agency (BPJS) in Surakarta City are factors of education and income. The results of the analysis show the Pearson chi square value of 84.282 with a significance of 0.000 . Because the significance value is $<0.05$, then $\mathrm{Ho}$ is rejected and it is stated that there is a significant relationship between education and community perceptions of the quality of public health services in Surakarta City BPJS. While the income aspect obtained Pearson chi square results of 21.204 with a significance of 0.047 . Because the significance value is $<0.05$, then $\mathrm{Ho}$ is rejected and it is stated that there is a significant relationship between Income and community perceptions of the quality of public services in the Surakarta City Health BPJS.

\subsection{Suggestion}

Based on the conclusions above, then in this study suggest the following:

1) For the Surakarta BPJS Health Office

It is expected that the BPJS Health Office can improve services as a whole, improve cooperation with related parties in order to provide services to the community. For this reason, the head of the BPJS office should be able to improve facilities and infrastructure that support services, provide good supervision of employee performance and so on. It is hoped that the community will not be anxious and worried about the BPJS services in the hospital because BPJS services are the same as other services in terms of administration, nursing services and facilities and infrastructure.

2) For Further Researchers
It is expected that the next researcher examines the descriptive correlation method by looking at the factors that influence people's perceptions of the BPJS Office services seen from internal and external factors.

\section{REFERENCE}

Arikunto, S., 2002. Research Procedure: A Practice Approach. Revised Edition V, Jakarta: Rineka Cipta.

Budiyono. 2009. Statistics for Research (2nd Edition). Surakarta: UNS Press

Iskandar (Dr, M.Pd). 2008. Educational and Social Research Methodologies (Quantitative and Qualitative). Jakarta: GP Press.

Karyati, Sri Berdayati. 2006. Analysis of the Influence of Patient Perceptions About the Quality of Obstetrics and Gynecology Specialist Medical Services with Interest in Patient ReVisit at the Outpatient Installation of Sultan Agung Hospital in Semarang in 2006. Eprints.undip.ac.id:

Diponegoro University.

State Administration Agency. 2003. Preparation of Public Service Standards. Jakarta: LAN.

Muhadjir, Darwin. 2001. Public Policy Analysis. Yogyakarta: Hanindita GrahaWidia.

Narbuko, Cholid and Abu Achmad. 2012. Research Methodology. Jakarta: Bumi Aksara. 
International Journal of Economics, Business and Accounting Research (IJEBAR)

Peer Reviewed - International Journal

Vol-2, Issue-4, 2018 (IJEBAR)

ISSN: 2614-1280

http://www.jurnal.stie-aas/ijebar

Nasucha, Chaizi (Dr). 2004. Public Administration Reform (Theory and Practice). Jakarta: Gramedia Widiasarana Indonesia

Nimran, Umar (Prof., Dr., M.A.). 1997. Organizational Behavior. Surabaya: Citra Media

Novandy, Riwan. 2009. Analysis of Community Perceptions of the Quality of Public Services in the Public and Community Welfare Administration Simalungun District Government 2009. repository.usu.ac.id. University of Northern Sumatra.

Noviansyah, Christian. 2006. Community Perception of Health Insurance Programs for the Poor. Jurnal.ugm.ac.id: Public Medicine News, Vol. 22 No. 3, September 2006.

Ningrum, Rinda Mustika et al. 2014. The Relationship between BPJS Health Service Quality Against Patient Satisfaction in the Digital ENT Polyclinic Dr. Ramelan Surabaya. Surabaya: STIKES Hang Tuah.

Regulation of the Head of State Administration Agency Number 10 of 2011 concerning Guidelines for the Implementation of Public Service Education and Training.

Riduwan (Dr, MBA). 2013. Methods and Techniques for Developing Theses. Bandung: Alfabeta.

Sugiyono, 2006. Business Research Methods. Eighth print. Bandung: CV. Alfabeta

Republic of Indonesia Law Number 24 of 2011 concerning the Social Security Organizing Agency

Law of the Republic of Indonesia Number 25 of 2009 concerning Public Services 